\title{
Dendritic cell density and activation status in human breast cancer - CDIa, CMRF-44, CMRF-56 and CD-83 expression
}

\section{BJ Coventry*,', P-L Lee', D Gibbs² and DNJ Hart ${ }^{3}$}

'Department of Surgery, University of Adelaide, Royal Adelaide Hospital, North Terrace, Adelaide, South Australia 5000, Australia; ${ }^{2}$ Haematology/lmmunology Research Group, University of Otago, Canterbury Health Laboratories, PO Box 151, Christchurch, New Zealand; ${ }^{3}$ Mater Medical Research Institute,

Mater Hospital, Brisbane, Queensland 4101, Australia

Low CDIa-positive putative dendritic cell numbers in human breast cancer has recently been described and may explain the apparent 'poor immunogenicity' previously reported in breast cancer. Little attention has been given to dendritic cell activation within the tumour microenvironment, which is another reason why the in-situ immune response may be severely deficient. We have therefore examined CD la expression as a marker for dendritic cells, together with CMRF-44 and -56 as markers of dendritic cell activation status, in 40 human breast cancers. The results demonstrate few or no CDIa-positive putative dendritic cells and minimal or no expression of the dendritic cell activation markers. Both dendritic cell number and dendritic cell activation appear substantially deficient in human breast cancers, regardless of tumour histological grade.

British Journal of Cancer (2002) 86, 546-55I. DOl: 10.1038/sj/bjc/6600I32 www.bjcancer.com

(c) 2002 Cancer Research UK

Keywords: dendritic cells; breast carcinoma; CDIa; CMRF-44; CMRF-56; CD83; DC activation

Breast adenocarcinoma has traditionally been thought of as a 'nonimmunogenic' tumour, despite numerous observations concerning the notable density of the T-cell infiltrate in human and animal breast cancers (Zhang et al, 1998). However, specific anti-tumour responses by autologous $\mathrm{T}$-lymphocytes infiltrating human breast tumours have been documented using short-term cultured breast carcinoma cells in-vitro (Baxevanis et al, 1994), and more widespread interest in the possibility of generating immunotherapeutic responses against breast cancer has developed. Dendritic cells (DC) have been identified as the specialist leukocyte population capable of initiating and directing immune responses. Studies of gastric, thyroid, lung and colorectal carcinomas have shown that the density of putative dendritic cells (DC) (CD1a; S-100 positive) is a predictor of survival (Tsujitani et al, 1987, 1988, 1990, 1992; Ambe et al, 1989; Schroder et al, 1988; Zeid and Muller, 1993). Equally, more recent studies suggest minimal recruitment and activation of DC in renal, prostate and bladder cancers (Troy et al, 1998a,b, 1999) and that S-100 staining may correlate with an activated DC subset (Troy et al, 1998a). Moreover, it has been shown that there is an inverse correlation between tumour differentiation grade and the DC infiltrate for some tumour types (Becker, 1992). Recent studies have demonstrated a low number of CD1a positive cells in human breast carcinomas (Hillenbrand et al, 1999) and these have been able to be extracted using specific dissaggregation techniques (Coventry et al, 1997). CD1a molecules appear to be expressed on epithelial associated DC during the antigen capture and processing phase, reducing in density as the DC phenotype develops full capacity for antigen presentation in-vivo. The possibility that the "nonimmunogenicity' of breast cancers may, in part, be due to low

*Correspondence: Dr BJ Coventry;

E-mail: brendon.coventry@adelaide.edu.au

Received 19 November 200I; accepted 4 December 200 I
DC infiltration, loss of DC from the tumour microenvironment or lack of DC activation, requires further investigation.

DC are derived from bone marrow precursors and recent data suggests that there are epithelial and non-epithelial associated subsets, distinguishable on the basis of CD1a expression. Surveillance DC require defined 'danger' signals derived from microbial organisms triggered by the innate immune response (perhaps lacking in some cancers) to initiate antigen uptake, migration and differentiation/ activation of DC co-stimulatory activity. Further control of DC co-stimulatory activity occurs as a result of the DC/ T-cell interaction (Hart, 1997). Acquisition of CD86 is an important end point of DC differentiation, signifying full co-stimulatory capacity (Thomas and Lipsky, 1996; Hart, 1997; McLellan et al, 1999). Recent evidence suggests other mechanisms may downregulate DC activation, depending on DC maturity (McLellan et al, 2000)

Effective antigen presentation within the tumour microenvironment for specific anti-tumour immune responses might be associated with differentiated, activated DCs. Equally it is possible that tumours may fail to recruit DC or activate DC thereby evading an effective anti-tumour response. CMRF-44 monoclonal antibody $(\mathrm{mAb})$ acts as a marker of allostimulatory activity in cultured peripheral blood mononuclear cells (Hock et al, 1994; Vuckovic et al, 1998), and defines an early differentiation activation marker on DC present on only a small number of peripheral tissue DC. Likewise the mAb CMRF-56 reacts with another early activation antigen expressed in high density on DCs, but not with other resting or activated leukocytes (Hock et al, 1999). Both of these markers show a strong correlation with a third DC differentiation/ activation antigen CD83 (Zhou and Tedder, 1995) as well as the up-regulation of cells and other cytoplasmic markers. Interleukin 10 (IL10) expression as a potential inhibitor of T-cells and DC is considered and discussed.

This study investigates the expression of the epithelial DC marker CD1a with that of CMRF-44, CMRF-56 and CD83 to determine the activation state of DC in human breast cancer. 


\section{MATERIALS AND METHODS}

The studies were performed in two collaborating laboratories and are reported in two parts - Part I (Adelaide) and Part II (Christchurch). The studies were approved by and met the ethical standards of both institutions.

\section{Tissues and processing}

Part I Fresh tissue was frozen in liquid nitrogen from samples taken at routine surgery from 30 infiltrating ductal breast carcinomas (IDC) (IDC grade I =10, IDC grade II $=10$, IDC grade III $=10$ ), then stored at $-80^{\circ} \mathrm{C}$ for later use. Samples were cut from intratumoural portions of tumours that were palpable (rather than mammographically detected). Four to five $\mu \mathrm{m}$ serial sections (Leica Cryostat) were mounted on gelatinized slides, left overnight, fixed in cold $\left(4^{\circ} \mathrm{C}\right)$ acetone for $10 \mathrm{~min}$ and air dried for a minimum of $2 \mathrm{~h}$.

All sections were pre-blocked with $10 \%$ goat or normal horse serum in phosphate-buffered saline (PBS) for $20 \mathrm{~min}$.

Part II Ten cases of breast cancer were obtained, frozen in liquid nitrogen and processed similarly.

\section{Immunohistochemical techniques}

Monoclonal antibodies Part I Mouse monoclonal anti-human antibodies, diluted in $10 \%$ normal horse serum (NHS), were used at the following concentrations, CDla at 1/500 (Dako, Denmark), CMRF 44 and CMRF 56 both at 1/50 (D Hart, New Zealand), mouse isotype negative control $2 \mu \mathrm{g} \mathrm{ml}^{-1}$ (Zymed, CA, USA). The anti-interleukin 10 antibody 12G8 (IgG; Schering, NJ, USA) was used at 1/500 dilution in separate studies briefly mentioned here. Biotinylated rabbit anti-mouse $\operatorname{IgG} / \operatorname{IgM}$ second antibody at 1/500 (Dako, Denmark), and streptavidin-HRP at 1/1000 (Pierce, USA). Single-staining protocol reactions were carried out at room temperature. PBS $\times 3$ rinses were used after each staining step. Following blocking with $10 \%$ NHS, sections were incubated for $1 \mathrm{~h}$ with the primary antibody, (CD1a for $1 \mathrm{~h}$, or CMRF 44/56 overnight).

Part II The anti-CD3 (OKT3, IgG $\left.\mathrm{I}_{2 \mathrm{a}}\right)$, antibody was produced from a hybridoma obtained from the American Type Culture Collection (ATCC, Rockville, MD, USA). The antibodies CMRF$12\left(\mathrm{CD} 45, \mathrm{IgG}_{1}\right), \mathrm{CMRF}-15$ (negative control, IgM), CMRF-31 $\left(\mathrm{CD} 14, \mathrm{IgG}_{2 \mathrm{a}}\right.$ ), CMRF-56 (activation antigen, IgG $\mathrm{I}_{1}$ ) and CMRF44 (activation antigen, IgM) were produced and characterized in this (DNJH) laboratory. The anti-CD83 mAb was purchased from Immunotech. The anti CD16 mAb (HuNK-2, IgG $\left.\mathrm{Ig}_{2 \mathrm{a}}\right)$ was a gift from Professor IFC McKenzie (Melbourne, Australia). The CD1a $\mathrm{mAb}\left(\mathrm{Na} 1 / 34, \mathrm{IgG}_{2 \mathrm{a}}\right)$, was a gift from Dr A McMichael (UK). The negative control mAb Sal5 $\left(\operatorname{IgG}_{2 \mathrm{a}}\right)$ and X63 $\left(\operatorname{IgG}_{1}\right)$, were gifts from Professor H Zola (Adelaide, Australia). Phycoerythrin-conjugated anti-CD45 and HLA-DR were purchased from Becton Dickinson (Australia). PE-conjugated anti-CD83 was purchased from Immunotech.

\section{Immunoperoxidase labelling}

Part I Biotinylated secondary antibody for $1 \mathrm{~h}$. Endogenous peroxide blocking (PBS and $0.5 \% \mathrm{H}_{2} \mathrm{O}_{2}$ for $20 \mathrm{~min}$ ) was followed by a $1 \mathrm{~h}$ incubation in SHRP. Sections were reacted with nickel chloride enhanced diaminobenzidene (DAB), and counterstained with methyl green (Coventry et al, 1994, 1995) for higher detection sensitivity. Lymph node sections from melanoma were used as positive controls.

Part II Specimens were cut, fixed and blocked as above. After incubation with the primary antibody, slides were washed three times in PBS and peroxidase-conjugated goat anti-mouse antibody (PGAM) (DAKO) applied. The slides were washed in tris buffered saline (TBS) then DAB applied. The reaction was terminated after $10-15 \mathrm{~min}$ by washing in PBS. Slides were counterstained, fixed and mounted as above.

\section{Immunofluorescence labelling}

Part II only Specimens were cut, fixed and blocked as above. The primary antibody mix was applied for $30 \mathrm{~min}$ at room temperature, then the slides were washed three times in PBS. Fluorescein isothyanate-conjugated sheep anti-mouse antibody (Silenus) was applied for $30 \mathrm{~min}$. After washing three times in PBS, the slides were blocked with $10 \%$ mouse serum for $10 \mathrm{~min}$. A Phycoerythrin-conjugated secondary antibody was applied for 30 min. After washing three times in PBS, the slides were mounted in glycerol-gelatin with DABCO as an anti-fade agent. Slides were stored in darkness at $-20^{\circ} \mathrm{C}$ and examined within $24 \mathrm{~h}$ of preparation.

\section{Characterization of cellular infiltrate}

Part I CD1a, CMRF 44 and 56 density assessment was performed by counting 50 random fields per frozen section, or as many fields as possible if the section was smaller. The mean of each section represented the density of the infiltrate (field size $0.375 \mathrm{~mm}$ diameter; $0.44 \mathrm{~mm}^{-2} ; 400 \times$ magnification). This allowed estimation of the density and distribution of different cell types in the infiltrate compared with $\mathrm{CDla}^{+}$staining to be expressed as cells per $\mathrm{mm}^{-2}$ (i.e. as in Part II).

Part II DC were identified in single label immunohistological studies by size, morphology and staining with the appropriate marker. The cells were counted in at least 10 medium power fields using a calibrated graticule, then the number of cells per $\mathrm{mm}^{-2}$ was calculated. DC were identified in double label immunofluorescence studies as $\mathrm{CD}_{4} 5^{+}$(i.e. Phycoerythrin labelled) cells that were negative (i.e. FITC negative) for the lineage markers CD3, CD14, CD16 and CD19.

\section{RESULTS}

\section{Identification of putative dendritic cells}

Part I CDla ${ }^{+}$cells were present in $50 \%$ of the breast tissue samples $(n=30)$. The density of the infiltrate was variable between samples (range $0.00-6.05 / \mathrm{HPF} ; \quad 0.00-13.75 \mathrm{~mm}^{-2}$; mean $=2.49$ cells $\mathrm{mm}^{-2}$ ).

There was no association between density of $\mathrm{CD}^{+}{ }^{+}$cells and tumour grade (Kruskal-Wallis, $P>0.05$ ).

DC occurred in small numbers relative to the number of $\mathrm{CD}^{+}$ cells. $\mathrm{CD}^{+}{ }^{+}$cells, probably epithelial DC, were present in the greatest numbers, as previously reported (Hillenbrand et al, 1999). The $\mathrm{CD} \mathrm{a}^{+}$cells tended to occur in loose clusters (distinct from lymphoid aggregates), so obtaining a count that accurately reflected their numbers was difficult. In some instances CD1a staining was thought to be present on a sub-population of macrophages.

Faint CMRF- $44^{+}$staining was observed in only one of the 30 breast carcinoma sections examined in this study (Figure 1), with the same sample demonstrating relatively strong CMRF- $56^{+}$immunostaining (Figure 2), with $\mathrm{CD}^{+} \mathrm{a}^{+}$cells found clustered around a tumour island (Figure 3). CD1a, CMRF-44 and -56 staining in normal breast tissues was sparse or absent.

Part II The immunoenzymatic staining identified a similar number of CD1a ${ }^{+}$DC in the second study $(n=10)$, with a similar range $\left(0-16.6 \mathrm{~mm}^{-2}\right)$. The mean number of $\mathrm{CD}^{+} \mathrm{a}^{+}$cells was $5.5 \mathrm{~mm}^{-2}$ and CD3 T-lymphocytes was $114.5 \mathrm{~mm}^{-2}$. Again 


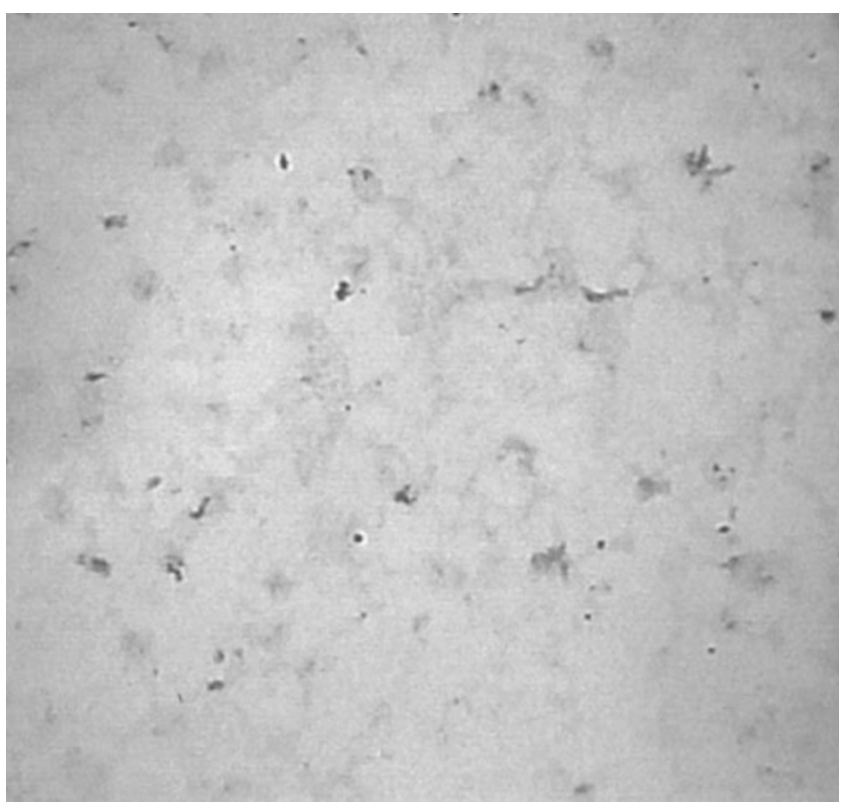

Figure I CMRF-44 staining in human breast cancer (Part I) $(\times 200)$.

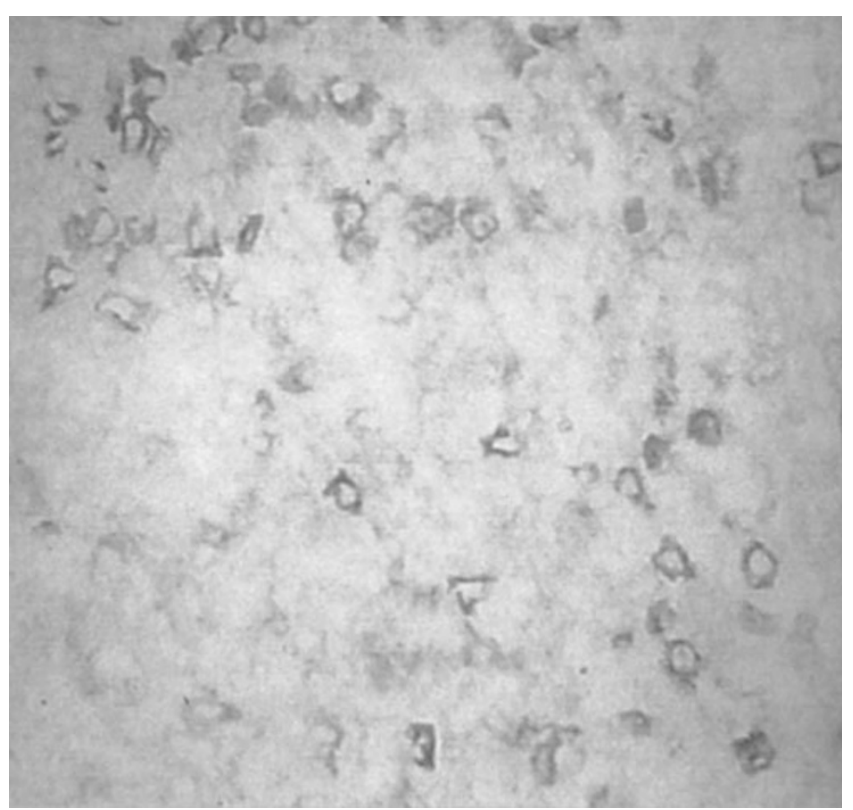

Figure 2 CMRF-56 positive cells in human breast cancer (Part I) $(\times 200)$.

limited staining with the activation markers was noted (CMRF 44 $>$ CD83 > CMRF-56). There was a trend for the activated DC to be associated with increased T-lymphocyte numbers (see below). The double label immunofluorescence studies identified very similar numbers of $\mathrm{Lin}^{-} / \mathrm{CD} 45^{+} \mathrm{DC}$, most of which were $\mathrm{CD} 1 \mathrm{a}^{+}$, but increased CDla staining on macrophages was evident in some cases. Counts were hampered by high non-specific background staining as a consequence of auto-fluorescence. Nonetheless, the CD1a counts obtained by this method were comparable with those obtained by immunohistochemistry. Comparing the lineage-negative cell counts and the $\mathrm{CDla}^{+}$cell counts suggests that a subset of DC in breast cancers express the epithelial DC marker CDla (Table 1).

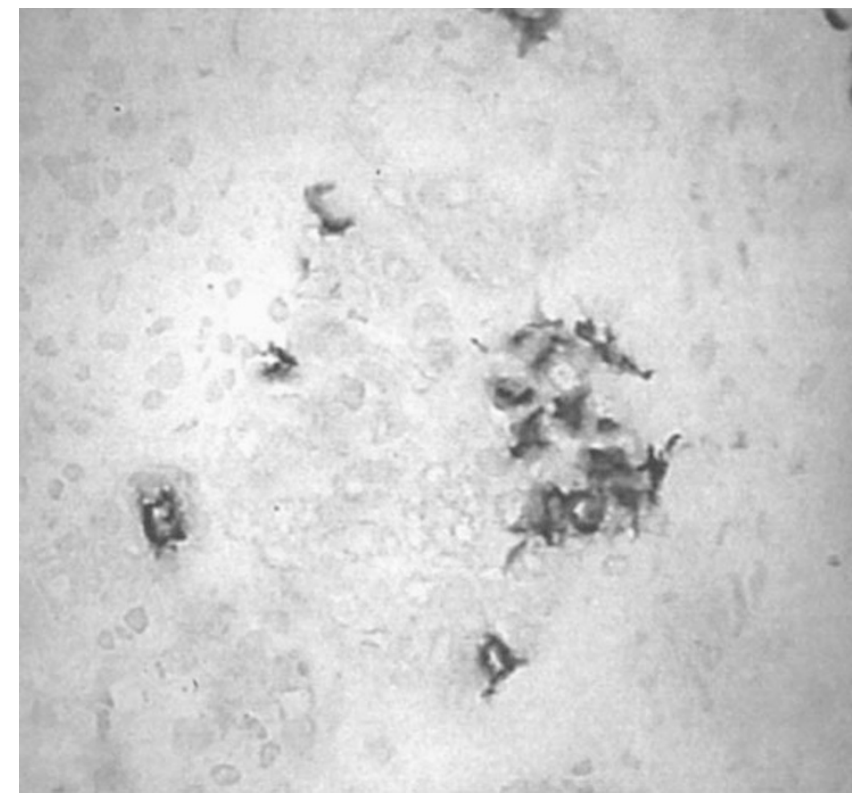

Figure 3 CD la positive cells in human breast cancer (Part I) $(\times 200)$.

\section{Identification of activated dendritic cells}

Although only one of 30 specimens was positive for CMRF-44 in Part I using DAB enhanced immunoenzymatic methods, limited numbers of CD83 and CMRF- $44^{+}$cells were identified in most specimens, using the alternative immunoenzymatic method or fluorescence method (Part II). CMRF- $56^{+}$cells were only identified in one specimen (for both Parts I and II; $n=40$ ) although other specimens had peri-tumoural lymphoid aggregates which contained cells that stained weakly with CMRF-56 (Table 1).

An attempt was made to assess co-expression of CDla and CD83 using immunofluorescence techniques but high background fluorescence made identification of phycoerythrin-labelled $\mathrm{CD} 83^{+}$ cells difficult. However, since no $\mathrm{CD} 1 \mathrm{a}^{+} / \mathrm{CD}^{2} 3^{+}$cells were identified (as few $\mathrm{CD}^{+}{ }^{+}$cells could be identified by indirect immunofluorescence) the conclusion that the two markers identify different populations of cells could not be established with certainty. Nonetheless, the immunofluorescence data confirmed the low number of $\mathrm{CD} 3^{+}$cells present.

Location of $\mathrm{CD}^{+} \mathrm{a}^{+}$cells $\mathrm{The} \mathrm{CDla}^{+}$cells were present in the stroma between islands of tumour cells and in more differentiated tumours were situated around the ductal formations.

Interleukin 10 in human breast cancer In a separate study IL10 expression was detected in 40 of 52 breast cancer specimens examined using immunohistochemical methods. The histological grade of the tumour did not correlate with the IL10 expression, nor did CD3 or CD68 expression. The IL10 staining intensity was low in all tumours and these cells were within the stroma around the ducts in well to moderately differentiated tissues (Neville, 1994).

\section{DISCUSSION}

The finding of paucity of $\mathrm{CDla}^{+}$cells in many of the breast carcinomas examined indicated that DC mediated co-stimulation of $\mathrm{T}$ lymphocytes in many breast cancers is likely to be severely deficient. It was also possible that CD1a negative DC may have been present and active within the tumour microenvironment. We excluded these possibilities by using lin- $\mathrm{CD} 45^{+}$staining for DC. 
Table I Fluorescence counts as indicated (Part 2)

\begin{tabular}{|c|c|c|c|c|c|c|c|}
\hline \multicolumn{4}{|c|}{ Fluorescence counts } & \multicolumn{2}{|c|}{ Per MPF } & \multicolumn{2}{|c|}{ Per $\mathbf{m m}^{2}$} \\
\hline Case & Histology & Grade & Stage & Lin $-/ 45+(F)$ & CDIa & Lin $-/ 45+(F)$ & CDIa \\
\hline I & IDC & 2 & $\|$ & 2.5 & 18 & 2.9 & 20.9 \\
\hline 2 & IDC & 3 & I & 3.4 & 0.4 & 3.9 & 0.5 \\
\hline 3 & $\mathrm{~N} / \mathrm{D}$ & N/D & $\mathrm{N} / \mathrm{D}$ & 3.6 & 0.5 & 4.2 & 0.6 \\
\hline 4 & IDC & 3 & $\|$ & 0 & 0 & 0 & 0 \\
\hline 5 & IDC & I & $N / D$ & 8 & I & 9.3 & 1.2 \\
\hline 6 & IDC & 2 & ॥ & 4.6 & 1.5 & 5.3 & 1.7 \\
\hline 7 & LOB & N/D & $\|$ & 5.3 & 0.13 & 6.1 & 0.2 \\
\hline 8 & N/D & N/D & $\mathrm{N} / \mathrm{D}$ & 8.5 & I.I & 9.9 & 1.3 \\
\hline 9 & N/D & N/D & N/D & 2 & 0.25 & 2.3 & 0.3 \\
\hline \multirow[t]{2}{*}{10} & Mucinous & & II & 4.6 & 3.8 & 5.3 & 4.4 \\
\hline & & & Means: & 4.3 & 2.7 & 4.9 & 3.1 \\
\hline
\end{tabular}

IDC=infiltrating ductal carcinoma; $L O B=$ lobular carcinoma; N/D=not defined.

To further investigate the DC present the CMRF-44, CMRF-56 and CD83 antibodies were used as another means of detecting DC and to assess their activation state. These studies showed that few mature or activated DC could be detected within breast tumours, implying that DC numbers and activation were indeed absent or very low in all but one tumour in the 30 tested.

It has been proposed that CDla acts as a lipid/carbohydrate carrying glycoprotein, similar in function to major histocompatability complex (MHC) molecules for peptides, with antigen presentation functions (Hillenbrand, 1994, Hillenbrand et al, 1999; Coventry, 1999). Interestingly, classical MHC molecules are frequently completely or partially lost from tumour cells with transition from in-situ to invasive growth (Garrido et al, 1993; Algarra et al, 2000). CDla appears to be internalized and/or downregulated as the DC matures and acquires the ability to present antigen more efficiently. The association between MHC and CD1a expression in tumours is currently unclear, but this study appears to exclude major down regulation of CD1a expression as an additional deficit.

DC are found in low numbers in other tumour types (Troy et al, 1998a,b, 1999) and the density of CD1a positive DC has been directly correlated with improved overall survival in many solid tumour types. The findings of the present study imply that many breast cancers not only fail to recruit DC but fail to drive DC into either the antigen capture/processing phase $\left(\mathrm{CDla}^{+}\right)$or the antigen presentation/co-stimulatory phase $\left(\mathrm{CMRF}-44 / 56^{+}\right)$. These latter findings suggest that the tumour environment may retard or fail to facilitate maturation/activation of DC. Interleukin 10 has been shown to exert an inhibitory role over T-lymphocyte reactions and as such has been suggested as a potential inhibitory molecule affecting tumour infiltrating lymphocytes (TIL) in the breast cancer microenvironment. Although IL10 showed very low expression it may exert significant inhibition of $\mathrm{T}$-cells in breast carcinoma (Neville, 1994).

DC migration may contribute to the common pathological finding of sinus histiocytosis, producing enlargement of regional, draining, non-tumour involved lymph nodes in primary breast (and other) tumours. This is a possible mechanism of induction of tumour tolerance (Steinbrink et al, 1999). Alternatively, mature DC may migrate or apoptose and be effectively lost from the primary tumour microenvironment (Esche et al, 1999; Pirtskhalaishvili et al, 2000). There is some evidence that anergic T-cells can induce apoptosis of DC (De Smedt et al, 1998; Vendetti et $a l, 2000)$, and that tumour cells can also cause DC apoptosis (Kiertscher et al, 2000).

Finally, it is unclear whether re-circulation of tumour antigen-loaded DC occurs back to the primary tumour, and whether this mechanism of T-cell activation may be defective.
Vascular endothelial growth factor (VEGF) is produced by tumours to produce neo-vascularization and can function as a local and systemic inhibitor of DC differentiation, maturation and function (Gabrilovich et al, 1997, 1998, 1999). Active suppression of DC function has been previously noted and was observed to be HLA Class II and CD4 mediated (McLellan et al, 1999).

TIL isolated from human solid tumours of different types, including breast carcinoma, have demonstrated poor proliferative responses to mitogens in-vitro which recovers after several days co-culture with interleukin-2 (IL-2), or after culture with antigen presenting cells (APC). In-situ studies of TIL in breast cancers demonstrate expression of the early activation markers CD38, 43 and 69, but show little or no expression of IL-2 receptor or IL2 protein (Coventry et al, 1996), suggesting anergic, tolerant Tcells. Collectively, these observations suggests that the TIL population in breast and other cancers is partially activated, but effectively rendered anergic. Tumour derived peptides loaded onto DC have been described to induce T-cell anergy (Grohmann et al, 1997), as one possible mechanism and again the absence of activated DC is entirely consistent with the possibility that these DC are providing tolerogenic signals. There is also evidence that anergic T-cells can inhibit antigen presenting functions of DC (Vendetti et al, 2000). In-vivo reversal of anergy using whole cell, peptide or membrane-lysate tumour vaccines which can induce tumour regression in some cases (Hersey, 1993; Soiffer et al, 1998; Haigh et al, 1999; Hart et al, 1999), but the mechanism remains unclear.

Nevertheless, some signs of activation are present in TIL in breast cancers which indicates that either T-cells were activated then became suppressed, or T-cell activation can by-pass the sparse, poorly activated DC within the tumour microenvironment to some minor degree. In either case, there is some optimism for the potential reversal of poor TIL activity and function using a variety of ex-vivo and in-vivo strategies to activate intra-tumoural DC, or to provide activated DC capable of effective antigen presentation to fully activate T-cells within the tumour. Recent work showing that the DC maturational type and activation differs between the intra-tumoural and peri-tumoural regions in a more advanced group of breast cancers supports our findings (Bell et al, 1999), and other work indicates DC maturation (and perhaps activation) can be induced by agents such as prostaglandins (Steinbrink et al, 2000). Taken collectively, these studies suggest that migration of DC capable of effective activation and antigen presentation into breast cancers may be defective and strategies leading to better DC migration may be required also, irrespective of how many potentially effective DC are delivered around the tumour. 


\section{ACKNOWLEDGEMENTS}

The authors wish to thank Evy Hillenbrand and Angela Neville (PhD students) for technical assistance with immunohistochemical staining, Eric Smith for technical photographic advice, Dr Chris Atkinson for encouragement and Drs Gill, Carter and Malycha for providing some of the tissues. Angela Neville supplied the IL10 work mentioned. Po-Ling Lee was supported in part by a

\section{REFERENCES}

Algarra I, Cabrera T, Garrido F (2000) The HLA crossroad in tumor immunology. Hum Immunol 61: 65-73

Ambe K, Mori M, Enjoji M (1989) S-100 protein-positive dendritic cells in colorectal adenocarcinomas. Distribution and relation to the clinical prognosis. Cancer 63: 496-503

Baxevanis CN, Dedoussis GV, Papodopoulos NG Missitzis I (1994) Tumour specific cytolysis by tumour infiltrating lymphocytes in breast cancer. Cancer 74: $1275-1282$

Becker Y (1992) Anticancer role of dendritic cells (DC) in human and experimental cancers - a review. Anticancer Res 12: 511 - 520

Bell D, Chomarat P, Broyles D, Netto G, Harb GM, Lebecque S, Valladeau J, Davoust J, Palucka KA, Banchereau J (1999) In breast carcinoma tissue, immature dendritic cells reside within the tumor, whereas mature dendritic cells are located in peritumoral areas. J Exp Med 190: 1417-1426

Coventry BJ, Neoh S, Mantzioris B, Skinner JM, Bradley J, Zola H (1994) Comparison of the sensitivity of immunoperoxidasestaining methods with high-sensitivity fluorescence flow cytometry - antibody quantitation on the cell surface. J Histochem Cytochem 42: 1143-1149

Coventry BJ, Bradley J, Skinner JM (1995) Differences between standard and high-sensitivity immunoperoxidase staining methods in tissue sections Comparison of immunoperoxidase staining methods using computerised video image analysis. Pathology 27: 221-224

Coventry BJ, Weeks S, Heckford S, Sykes P, Skinner J, Bradley J (1996) Lack of interleukin-2 (IL-2) cytokine expression despite IL-2mRNA transcription in tumour infiltrating lymphocytes in primary human breast carcinoma: selective expression of early activation markers. J Immunol 156: $3486-3492$

Coventry BJ, Austyn JM, Chryssidis S, Hankins D, Harris A (1997) Identification and isolation of CDla positive putative tumour infiltrating dendritic cells in human breast cancer. In Dendritic cells in Fundamental and Clinical Immunology Vol 3: P Ricciardi-Castagnoli (ed) Plenum Press: NY Adv Exptl Med Biol 417 571-577

Coventry BJ (1999) Review of CDla putative tumour infiltrating dendritic cells in human breast cancers. AntiCancer Res 19: $3183-3188$

De Smedt T, Pajak B, Klaus GG, Noelle RJ, Urbain J, Leo O, Moser M (1998) Antigen-specific T lymphocytes regulate lipopolysaccharide-induced apoptosis of dendritic cells in vivo. I Immunol 161: 4476-4479

Esche C, Lokshin A, Shurin GV, Gastman BR, Rabinowich H, Watkins SC, Lotze MT, Shurin MR (1999) Tumor's other immune targets: dendritic cells. J Leukoc Biol 66: 336-344

Gabrilovich DI, Corak J, Ciernik IF, Kavanaugh D, Carbone DP (1997) Decreased antigen presentation by dendritic cells in patients with breast cancer. Clin Cancer Res 3: $483-490$

Gabrilovich D, Ishida T, Oyama T, Ran S, Kravtsov V, Nadaf S, Carbone DP (1998) Vascular endothelial growth factor inhibits the development of dendritic cells and dramatically affects the differentiation of multiple hematopoietic lineages in vivo. Blood 92: 4150-4166

Gabrilovich DI, Ishida T, Nadaf S, Ohm JE, Carbone DP (1999) Antibodies to vascular endothelial growth factor enhance the efficacy of cancer immunotherapy by improving endogenous dendritic cell function. Clin Cancer Res 5: $2963-2970$

Garrido F, Cabrera T, Concha A, Glew S, Ruiz-Cabello F, Stern PL (1993) Natural history of HLA expression during tumour development. Immunol Today 14: $491-499$

Grohmann U, Bianchi R, Ayroldi E, Belladonna ML, Surace D, Fioretti MC, Puccetti P (1997) A tumor-associated and self antigen peptide presented by dendritic cells may induce T cell anergy in vivo, but IL-12 can prevent or revert the anergic state. J Immunol 158: $3593-3602$

Hart DN (1997) Dendritic cells: unique leukocyte populations which control the primary immune response. Blood 90: 3245-3287 summer vacation scholarship from the Anti-Cancer Foundation of the Universities of South Australia. The Health Research Council and Canterbury Medical Research Foundation also provided some support (DG; DNJH). The Royal Australasian College of Surgeons Florance Cancer Research Fellowship Award provided some funding (BJC). We are grateful for gifts of antibodies from Professors IFC McKenzie (Melbourne), H Zola (Adelaide), A McMichael (Oxford). The anti-interleukin 10 (12G8) antibody was kindly supplied by Schering, NJ, USA.
Hart DN, Schultze JL, Stewart AK (1999) Presentation of tumor antigens. Semin Hematol 36(Suppl 3): 21-25

Haigh PI, Difronzo LA, Gammon G, Morton DL (1999) Vaccine therapy for patients with melanoma. Oncology (Huntingt) 13: $1561-1574$

Hersey P (1993) Evaluation of vaccinia viral lysates as therapeutic vaccines in the treatment of melanoma. Ann NY Acad Sci 690: 167-177

Hillenbrand EE (1994) An immunohistochemical analysis of the distribution and density of CDla+cells in ductal carcinoma of the breast Honours Thesis University of Adelaide

Hillenbrand EE, Neville AM, Coventry BJ (1999) Immunohistochemical localisation of CD1a positive putative dendritic cells in human breast tumours. Br J Cancer 79: 940 - 944

Hock BD, Starling GC, Hart D (1994) Characterization of CMRF-44, a nove monoclonal antibody to an activation antigen expressed by allostimulatory cells within peripheral blood, including dendritic cells. Immunology 83: 573

Hock BD, Fearnley DB, Boyce A, McLellan AD, Sorg RV, Summers KL, Hart DN (1999) Human dendritic cells express a $95 \mathrm{kDa}$ activation/differentiation antigen defined by CMRF-56. Tis Anti 53: 320-334

Kiertscher SM, Luo J, Dubinett SM, Roth MD (2000) Tumors promote altered maturation and early apoptosis of monocyte-derived dendritic cells. J Immunol 164: 1269-1276

McLellan AD, Heiser A, Hart DN (1999) Induction of dendritic cell costimulator molecule expression is suppressed by $\mathrm{T}$ cells in the absence of antigen-specific signalling: role of cluster formation, CD40 and HLA-class II for dendritic activation. Immunology 98: 171-180

McLellan AD, Terbeck G, Mengling T, Starling GC, Kiener PA, Gold R, Brocker EB, Leverkus M, Kampgen E (2000) Differential susceptibility to CD95 (Apo-1/Fas) and MHC class II-induced apoptosis during murine dendritic cell development. Cell Death Differ 7: 933-938

Neville AM (1994) Breast Carcinoma - The role of Interleukins 2, 4 and IL10 in human breast cancers, Honours Thesis Adelaide University

Pirtskhalaishvili G, Shurin GV, Esche C, Cai Q, Salup RR, Bykovskaia SN, Lotze MT, Shurin MR (2000) Cytokine-mediated protection of human dendritic cells from prostate cancer-induced apoptosis is regulated by the Bcl-2 family of proteins. Br J Cancer 83: 506-513

Schroder S, Schwarz W, Rehpenning W, Loning T, Bocker W (1988) Dendritic/Langerhans cells and prognosis in patients with papillary thyroid carcinomas. Immunocytochemical study of 106 thyroid neoplasms correlated to follow-up data. Am J Clin Pathol 89: 295-300

Soiffer R, Lynch T, Mihm M, Jung K, Rhuda C, Schmollinger JC, Hodi FS Liebster L, Lam P, Mentzer S, Singer S, Tanabe KK, Cosimi AB, Duda R, Sober A, Bhan A, Daley J, Neuberg D, Parry G, Rokovich J, Richards L, Drayer J, Berns A, Clift S, Cohen LK, Mulligan RC, Dranoff G (1998) Vaccination with irradiated autologous melanoma cells engineered to secrete human granulocyte-macrophage colony-stimulating factor generates potent antitumor immunity in patients with metastatic melanoma. Proc Natl Acad Sci USA 95: 13141 - 13146

Steinbrink K, Jonuleit H, Muller G, Schuler G, Knop J, Enk AH (1999) Interleukin-10-treated human dendritic cells induce a melanoma-antigenspecific anergy in CD8(+) T cells resulting in a failure to lyse tumor cells. Blood 93: $1634-1642$

Steinbrink K, Paragnik L, Jonuleit H, Tuting T, Knop J (2000) Induction of dendritic cell maturation and modulation of dendritic cell-induced immune responses by prostaglandins. Arch Dermatol Res 292: 437-445

Thomas R, Lipsky E (1996) Could endogenous self-peptides presented by dendritic cells initiate rheumatoid arthritis?. Immunol Today 12: 559-564

Troy AJ, Summers KL, Davidson PJ, Atkinson CH, Hart DN (1998a) Minimal recruitment and activation of dendritic cells within renal cell carcinoma. Clin Cancer Res 4: 585-593 
Troy A, Davidson P, Atkinson C, Hart D (1998b) Phenotypic characterisation of the dendritic cell infiltrate in prostate cancer. J Urol 160: 214-219

Troy AJ, Davidson PJ, Atkinson CH, Hart DN (1999) CDla dendritic cells predominate in transitional cell carcinoma of bladder and kidney but are minimally activated. J Urol 161: $1962-1967$

Tsujitani S, Furukawa T, Tamada R, Okamura T, Yasumoto K, Sugimachi K (1987) Langerhans cells and prognosis in patients with gastric carcinoma. Cancer 59: $501-505$

Tsujitani S, Okamura T, Baba H, Korenaga D, Haraguchi M, Sugimachi K (1988) Endoscopic intratumoral injection of OK-432 and Langerhans' cells in patients with gastric carcinoma. Cancer 61: 1749-1753

Tsujitani S, Kakeji Y, Watanabe A, Kohnoe S, Maehara Y, Sugimachi K (1990) Infiltration of dendritic cells in relation to tumor invasion and lymph node metastasis in human gastric cancer. Cancer 66: 2012-2016

Tsujitani S, Kakeji Y, Watanabe A, Kohnoe S, Maehara Y, Sugimaghi K (1992) Infiltration of S100 protein positive Dendritic cells and peritoneal recurrence in advanced gastric cancer. Int Surg 77: 238-241
Vendetti S, Chai JG, Dyson J, Simpson E, Lombardi G, Lechler R (2000) Anergic $T$ cells inhibit the antigen-presenting function of dendritic cells. J Immunol 165: 1175-1181

Vuckovic S, Fearnley DB, Mannering SI, Dekker J, Whyte LF, Hart DN (1998) Generation of CMRF-44+ monocyte-derived dendritic cells: insights into phenotype and function. Exp Hematol 26: 1255-1264

Zeid NA, Muller HK (1993) S100 positive dendritic cells in human lung tumors associated with cell differentiation and enhanced survival. Pathology 25: $338-343$

Zhang XD, Schiller GD, Gill PG, Coventry BJ (1998) Lymphoid cell infiltration during breast cancer growth: A syngeneic rat model. Immunol Cell Biol 76: $550-555$

Zhou LJ, Tedder TF (1995) Human blood dendritic cells selectively express CD83, a member of the immunoglobulin superfamily. J Immunol 154: $3821-3835$ 